\title{
Functional aspects of Escherichia coli rep helicase in unwinding and replication of DNA
}

\author{
Irmtraud BÄUMEL, Thomas F. MEYER, and Klaus GEIDER \\ Max-Planck-Institut für medizinische Forschung, Abteilung Molekulare Biologie, Heidelberg
}

(Received August 16/October 28, 1983) - EJB 830898

\begin{abstract}
The gene for Escherichia coli rep helicase (rep protein) was subcloned in a $\mathrm{pBR}$ plasmid and the protein overproduced in cells transformed with the hybrid DNA. The effect of purified enzyme on strand unwinding and DNA replication was investigated by electron microscopy. The templates used were partial duplexes of viral DNA from bacteriophage fd: $\operatorname{Tn} 5$ and reannealed DNA from bacteriophage Mu. The experiments with the two DNA species show DNA unwinding uncoupled from replication. The single-stranded phage fd::Tn5 DNA with the inverted repeat of transposon Tn5 could be completely replicated in the presence of the $E$. coli enzymes rep helicase, DNA binding protein I, RNA polymerase and DNA polymerase III holoenzyme. A block in the unwinding step increases secondary initiation events in single-stranded parts of the template, as DNA polymerase III holoenzyme cannot switch across the stem structure of the transposon.
\end{abstract}

The Escherichia coli gene rep has been implicated with replication of small bacteriophages [1]. The enzymatic involvement of rep helicase in strand unwinding has been shown in vitro for replication of double-stranded phage $\phi$ X174 [2] and phage fd DNA [3].

The action of rep helicase in the fork depends on ATP or dATP as energy source [4]. The polarity of unwinding by rep helicase is opposite to the direction of strand separation found for other $E$. coli DNA helicases [5]. The rep helicase separates the strands in the direction of DNA replication on the leading strand. A general method to assay the action of DNA helicases is the degradation of single-stranded DNA generated by $\mathrm{S}_{1}$-endonuclease [6]. Partially unwound duplex DNA cannot be assayed by this method, as the strands will renature before completion of endonucleolytic degradation or endonucleolytic digest of partial duplexes cannot be distinguished from degradation of completely separated strands. However, electron microscopy is a convenient tool to study partial denaturation of double-stranded DNA [7].

The $E$. coli DNA helicases I, II and III require a DNA duplex to be partially single-stranded in order to unwind DNA [8]. E. coli rep helicase can initiate DNA unwinding at a nick if a helper protein like gene 2 protein for phage fd [3] or gene A protein for phage $\phi \times 174$ DNA is present [9]. In the absence of these phage-specific proteins, unwinding by rep helicase also depends on single-stranded regions in the duplex DNA [10]. The enzyme might also be involved in replication of the host chromosome. Defects in the coding gene results in increased fork initiation [11]. The rep mutation does not seem compatible with the non-functional $u v r D$ gene product (DNA helicase II) [12]. It has therefore been assumed that E. coli rep helicase and DNA helicase II simultaneously unwind the two strands in a replication fork.

Here we will describe electron microscopical investigations on enzymatic strand separation by $E$. coli rep helicase in the presence of $E$. coli DNA binding protein I. It will be shown that DNA replication by DNA polymerase III holoenzyme on a

Abbreviation. RF, replicative form DNA of small bacteriophages. single-stranded template can be blocked by stable, base-paired regions, if they are not enzymatically unwound. This eventually leads to unspecific initiation events on single-stranded areas of the molecule.

\section{MATERIALS AND METHODS}

\section{Enzymes}

The preparation of the proteins used in the assays have been described for fd gene 2 protein [13], Escherichia coli DNA polymerase III holoenzyme [3], and $E$. coli DNA binding protein I [14]. rep helicase was isolated from overproducing cells described below by using a published procedure [15]. One unit is defined as the amount catalyzing the synthesis of 1 pmol of deoxynucleotide into phage fd RF under conditions described for the standard replication assay [3]. RNA polymerase holoenzyme was prepared according to Burgess and Jendrisak [16]. The concentration of proteins was determined according to the dye absorption method of Glick [17] and verified on polyacrylamide gels by Coomassie blue staining.

\section{$D N A$}

Phage $\mathrm{Mu}$ and phage fd DNA were extracted from phage particles. Phage fd: : Tn 5 (fd-30) was obtained by R. Herrmann [18]. Phage $\mathrm{Mu}$ CIts, $\Delta 445-7$, gin $^{-}, \mathrm{G}(+)$ was kindly provided by D. Kamp. As substrate for strand unwinding, Mu DNA was alkali-denatured, neutralized with acid, heated to $50^{\circ} \mathrm{C}$ and slowly cooled. Reannealing was found to be complete as judged by screening in the electron microscope.

\section{Cloning of the rep gene}

A DNA segment carrying the $E$. coli rep gene was derived from plasmid pLC 44-7 [19]. This plasmid DNA was cleaved with $H$ indIII endonuclease and the fragments inserted into the gene for tetracycline resistance of plasmid pBR322 [20]. After ligation, the hybrid plasmids were transferred into strain H517 


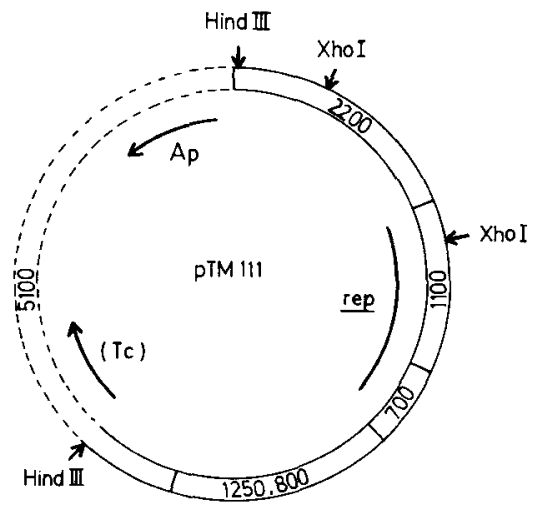

Fig. 1. Physical map of a DNA fragment with the E. coli rep gene cloned into the HindIII site of plasmid $P B R 322$. The ends of the segments in the circle indicate $E c o$ RI sites. The length of the fragments is given in base pairs. Two fragments $(1250,800)$ were not precisely localized

$\left(\mathrm{F}^{+}\right.$, rep $\left.^{-}\right)$. Selection of transformants was done on plates with ampicillin. Tetracycline-sensitive colonies were inoculated in $\mathrm{TC}$ medium and the cells were plated on righ agar. To screen for rep ${ }^{+}$cells, droplets with phage $\phi \times 174$ or fd were applied to the surface. These phages can only be propagated on E. coli cells with a functional rep gene. Cells from positive clones were used for the isolation of rep helicase. A restriction map of plasmid pTM111 is presented in Fig. 1. Further subcloning of the fragment with the rep gene did not produce stable plasmids expressing rep helicase.

\section{Strand unwinding}

DNA of phage fd: $: \operatorname{Tn} 5$ was unwound by adding $54 \mathrm{ng}$ fd: : Tn 5 single-stranded DNA, $550 \mathrm{ng}$ DNA binding protein I and 5 units of rep helicase to $10 \mu$ of unwinding buffer $(20 \mathrm{mM}$ Hepes, pH $7.5 ; 100 \mu \mathrm{g} / \mathrm{ml}$ bovine serum albumin, $5 \mathrm{mM}$ 2-mercaptoethanol, $5 \mathrm{mM} \mathrm{MgCl} 2,70 \mu \mathrm{M}$ ATP). Incubation was done for $20 \mathrm{~min}$ at $30^{\circ} \mathrm{C} .140 \mathrm{ng}$ of reannealed Mu DNA were incubated for unwinding with $1500 \mathrm{ng}$ of $E$. coli DNA binding protein I and 15 units of rep helicase in $10 \mu 1$ unwinding buffer for $20 \mathrm{~min}$ at $30^{\circ} \mathrm{C}$. Unwinding was measured by electron microscopy.

\section{DNA replication}

Replication with DNA polymerase III holoenzyme was done in $10 \mu \mathrm{l}$ of replication buffer containing $40 \mathrm{mM}$ Hepes, $\mathrm{pH} 7.5 ; 80 \mu \mathrm{g} / \mathrm{ml}$ bovine serum albumin, $4 \mathrm{mM}$ 2-mercaptoethanol, $5 \mathrm{mM} \mathrm{MgCl}_{2}$ and $4 \%$ sorbitol for $20 \mathrm{~min}$ at $30^{\circ} \mathrm{C}$. Nucleotide concentrations were $500 \mu \mathrm{M}$ ATP, $250 \mu \mathrm{M}$ each of CTP, GTP, and UTP, $50 \mu \mathrm{M}$ each of dATP, dGTP, and dTTP and $25 \mu \mathrm{M}\left[\alpha_{-}{ }^{32} \mathrm{P}\right] \mathrm{dCTP}(500 \mathrm{cpm} / \mathrm{pmol})$. The assay mixture contained $8 \times 10^{9}$ molecules of single-stranded DNA, which is $54 \mathrm{ng}$ DNA from phage fd : : Tn5 or $29 \mathrm{ng}$ DNA from phage fd wild type, in addition to $300 \mathrm{ng}$ RNA polymerase holoenzyme, 15 units of DNA polymerase III holoenzyme, $550 \mathrm{ng}$ DNA binding protein I and, if indicated, 5 units of rep helicase.

\section{Electron microscopy}

The reactions were stopped by addition of EDTA. Sorbitolcontaining samples were centrifuged through tubes with Sepharose CL6B. The DNA was spread by modifying the cytochrome $c$ /formamide technique of Davis and Davidson
[21]. DNA was diluted to $0.5 \mu \mathrm{g} / \mathrm{ml}$ in $0.1 \mathrm{M}$ Tris $/ \mathrm{Cl}, \mathrm{pH} 8.1$; $10 \mathrm{mM}$ EDTA, $0.005 \%$ cytochrome $c$ and $40 \%$ formamide and spread onto a hypophase of double-distilled water. The film was picked up with parlodion-coated grids, stained with uranyl acetate, dehydrated in $90 \%$ ethanol and rotary shadowed with tungsten. Photographs were taken with a Philips electron microscope EM 400.

\section{RESULTS}

\section{Substrates for DNA unwinding with rep helicase}

For the unwinding studies we have chosen two distinct partially double-stranded DNA templates, i.e. reannealed bacteriophage Mu DNA (Fig. 2A) and single-stranded bacteriophage fd DNA which carries an insertion of transposon 5 in the intergenic region (Fig. $3 \mathrm{~A}, \mathrm{~B}$ ). Mu DNA is flanked at one end by a short heterogeneous host DNA sequence of about 100 nucleotides, at the other end by a longer host DNA sequence of about 3000 nucleotides [22]. Denaturation of the Mu DNA and subsequent reannealling results in non-pairing ends, because the population of molecules is only homologous in the viral part of the DNA sequence, whereas the host sequence attached is random. In phage $\mathrm{fd}::$ Tn 5 DNA, the transposon consists of 2300 nucleotides with an inverted repeat of 1500 nucleotides, forming a stem or paired DNA, which has to be unwound before a DNA polymerase can replicate this region. Both DNA species were incubated with rep helicase and Escherichia coli DNA binding protein I and subsequently spread for electron microscopy. Fig. 2B shows a typical molecule of Mu DNA with partially unwound strands. Strand unwinding by rep helicase was observed for $4 \%$ of the molecules, the rest was found in the original conformation. In a quantitative estimation only partially unwound molecules were seen, which could be distinguished from the template molelcules by longer singlestranded and shorter double-stranded regions. The enzyme can apparently not unwind the whole length of $\mathrm{Mu}$ DNA. As shown in Fig. $3 \mathrm{C}$ rep helicase is able to unwind the partially base-paired DNA of fd: $: \operatorname{Tn} 5$. Similar to the result for $\mathrm{Mu}$ DNA, $4 \%$ of the molecules were unwound, but spontaneous reannealing could already have occurred during the unwinding reaction before spreading for the electron microscopic picture. Other ratios of rep helicase and DNA binding protein with respect to the DNA substrate did not improve the amount of separated DNA strands visualized. The addition of glyoxal to the reaction mixture immediately at the end of the incubation time also did not increase the percentage of unwound molecules. The low, but distinct, percentage of unwound molecules therefore may not necessarily reflect an optimum for the unwinding reaction rather than an equilibrium of strand separation and reannealing. If the unwinding reaction was performed in the absence of DNA binding protein I, strand separation was not observed in the electron microscopic assay.

\section{Effects of rep helicase on conversion of $f d:$ : Tn5 single-strand to $R F$ DNA}

It has been shown previously that single-strand to RF conversion of $\mathrm{fd}$ viral strands by a multi-protein system is initiated at position 5758 on the phage genome [23]. This system consisted of $E$. coli DNA binding protein I, RNA polymerase, and DNA polymerase III holoenzyme [24] and was also used for replication of phage $\mathrm{fd}:: \operatorname{Tn} 5$ DNA. Since in $\mathrm{fd}:: \operatorname{Tn} 5$ DNA the transposon is inserted at nucleotide 5559 (Fig. 3) [18], the 

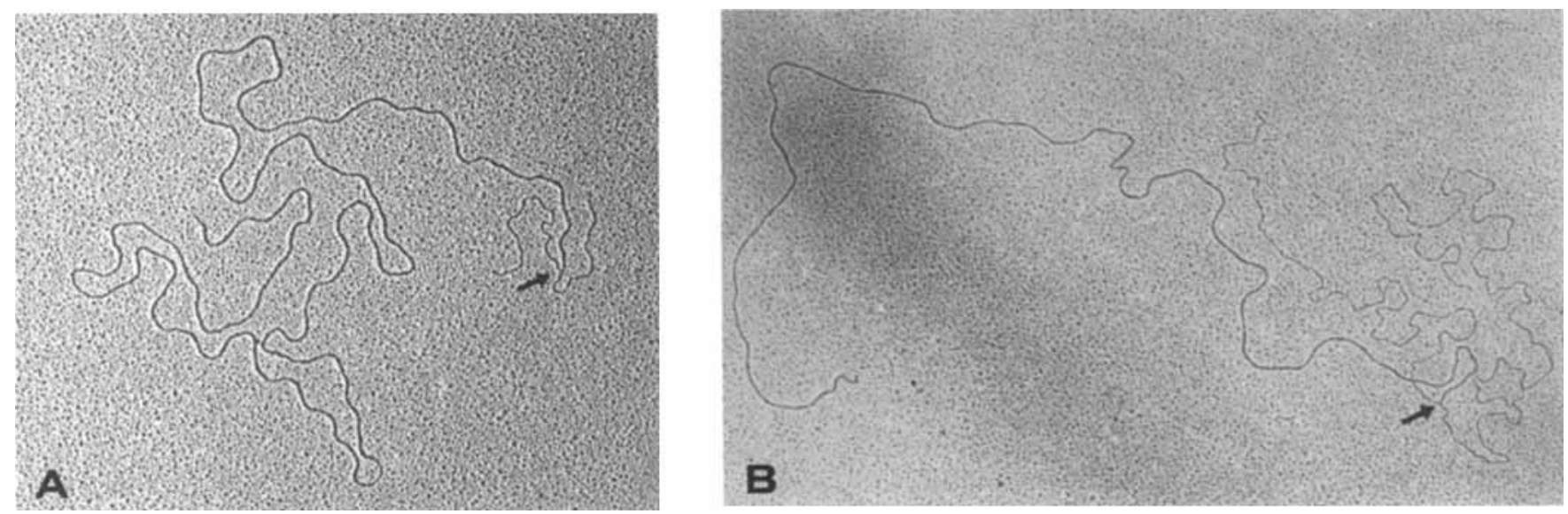

Fig. 2. Phage Mu DNA with unpaired termini and its unwinding by rep helicase. (A) Renatured Mu DNA as described in Materials and Methods; (B) Mu DNA partially unwound by rep helicase. Forks are indicated by arrows. Magnification was 6500 -fold. 110 molecules were evaluated
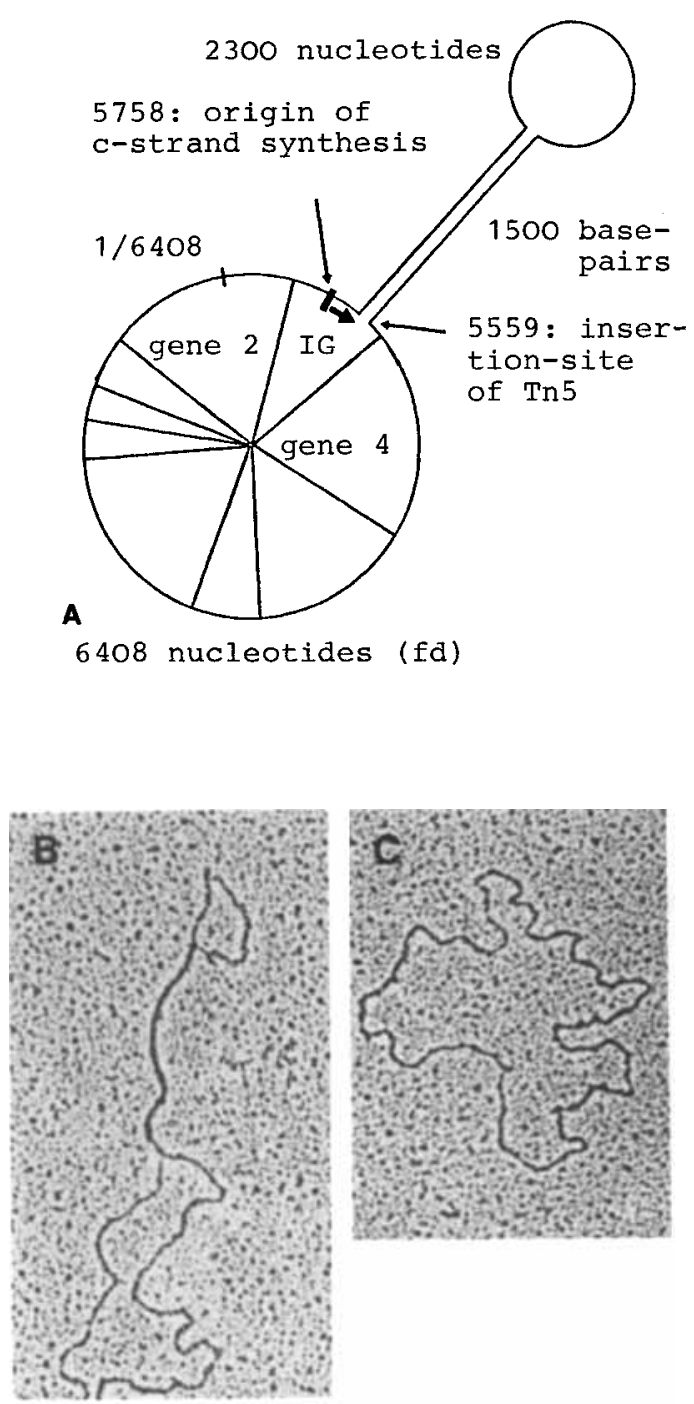

Fig. 3. Structure and enzymatic unwinding of phage fd DNA with an insertion of transposon 5 ( $f d-30$ ) [18]. (A) Genetic and physical map of the DNA from phage fd-30. (B) Electron microscope picture of the single-stranded DNA from phage fd-30. (C) DNA from the phage unwound by rep helicase. The reaction mixture and the electron microscopic investigation are described in Materials and Methods. 150 molecules were evaluated. Magnification was 10800 -fold
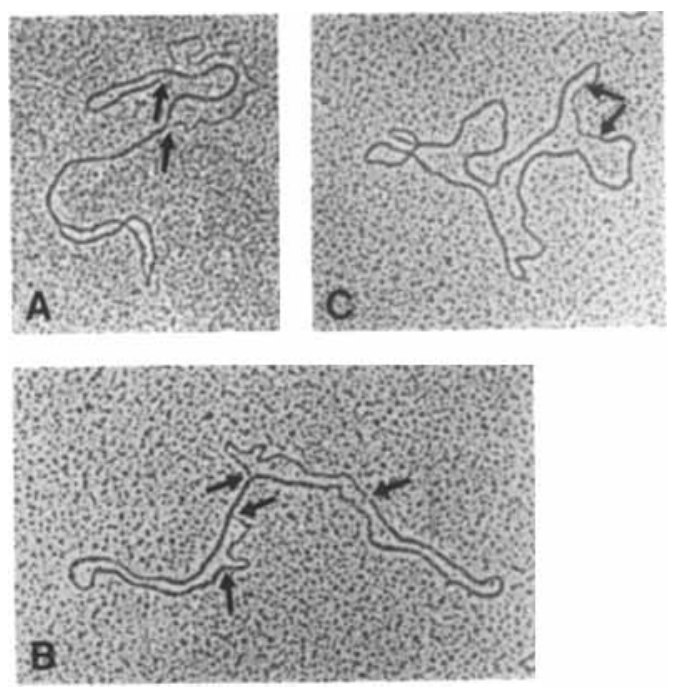

Fig. 4. The effect of rep helicase on replication of $f d:: T n 5 D N A$ by $D N A$ polymerase III holoenzyme. (A) Replication in the absence of rep helicase (30-min incubation). (B and C). Replication in the presence of rep helicase; (B) incubation for $10 \mathrm{~min}$; (C) incubation for $30 \mathrm{~min}$. The transition of single-stranded to double-stranded DNA is indicated by arrows. Magnification was 10800 -fold

RNA primer should only be extended for about 170 deoxynucleotides until the polymerase reaches the doublestranded stem of the insert. Our data for DNA synthesis with $\mathrm{fd}:: \operatorname{Tn} 5$ single strands are consistent with the assumption that DNA polymerase III holoenzyme cannot cross a fork, in contrast to DNA polymerase I [25] or to phage T7 DNA polymerase [26]. After a block for DNA synthesis of DNA polymerase III holoenzyme by the transposon insert, initiation of the conversion of single strands to RF DNA appeared to occur at secondary sites (Fig. 4A). We observed initiation of replication at various sites on the fd genome, as well as in the loop structure of the transposon DNA, resulting in multiple starts of DNA synthesis on the same template molecule (Fig. 4). The occurrence of single-stranded and double-stranded DNA can be judged by the shape of areas in the molecule. Kinky patches suggest single-stranded DNA. An independent measurement for unwinding can be derived from the length of 
Table 1. Single-strand to RF conversion of $f d:$ :Tn5 DNA in the presence and in the absence of rep helicase

The replication was performed for $20 \mathrm{~min}$ with DNA binding protein I, RNA polymerase and DNA polymerase III holoenzyme with rep helicase, if indicated, and fd: :Tn5 DNA as template, as described in Materials and Methods. The products were investigated by electron microscopy. Double-stranded DNA could be distinguished as solid bars in contrast to thinner kinky contours of single-stranded DNA. Replication from the normal fd origin to the transposon insert (170 base pairs) and subsequently halt was concluded by the appearance of secondary initiation events resulting in an extension of the doublestranded DNA from the stem into the loop structure (see Fig. 4A). The identified structures are given as a percentage of total molecules

\begin{tabular}{lll}
\hline Replication type & Proportion \\
\cline { 2 - 3 } & $\begin{array}{l}\text { with } \\
\text { rep helicase }\end{array}$ & $\begin{array}{l}\text { without } \\
\text { rep helicase }\end{array}$ \\
\hline & $\%$ & \\
\cline { 2 - 3 } & 9 & 11 \\
No replication & 53 & 88 \\
$\begin{array}{l}\text { Replication to stem of Tn5 and } \\
\text { secondary initiation } \\
\text { Unwinding and replication of the } \\
\text { stem structure }\end{array}$ & 38 & 1 \\
\hline
\end{tabular}

Total number of molecules evaluated 126

117

the stem structure relative to the whole fd: : Tn 5 molecule. Full length is observed for the molecule shown in Fig. 4A, residual pairing is seen in Fig. $4 \mathrm{~B}$ and complete strand separation is demonstrated in Fig. 4C. As concomitant replication prevents strand reannealing, circles without loops are strongly increased (Table 1).

Addition of rep helicase to the replication proteins stimulated enzymatic replication with $\mathrm{fd}:: \operatorname{Tn} 5$ single strands for about $30 \%$ compared to DNA synthesis in the absence of rep helicase, but did not show any effect on the incorporation kinetics with wild-type fd single strands (data not shown). During the first minutes of incubation the action of rep helicase allowed DNA synthesis to intrude into the stem of the transposon (Fig. 4B). When the incubation time was extended to $30 \mathrm{~min}$ the base-paired structure was separated and the whole DNA formed a large double-stranded circle (Fig. 4C). At this stage gaps in the DNA were used for further unwinding which resulted in double-stranded molecules with singlestranded tails. Branches were not found for the conversion of wild-type fd single strands to RF DNA (data not shown). This suggests that the normal replication origin with its four hairpin structures may prevent unwinding events, whereas secondary initiation as seen in $\mathrm{fd}:: \mathrm{Tn} 5$ creates sites of single-stranded DNA which can be subsequently unwound by rep helicase in the presence of DNA binding protein $\mathrm{I}$.

A quantitative evaluation of single-strand of RF conversion of $\mathrm{fd}:: \operatorname{Tn} 5$ DNA in the absence and in the presence of rep helicase is given in Table 1. Replication in the absence of rep helicase most often resulted in an early stop at the site of the transport insert, which was accompanied with a second initiation event visible as an extension of the double-stranded region as demonstrated in Fig. 4A. Replication possibly starts in the molecule shown about 3000 nucleotides from the insertion site of $\operatorname{Tn} 5$ and stops at the double-stranded stem. This was judged by the appearance of the complete stem and the thick contour of DNA in half of the large loop. The addition of rep helicase resulted in unwinding of the stem structure seen by the conversion of large parts of the $\mathrm{fd}:: \mathrm{Tn} 5$ DNA into the double-stranded form (Fig. 4B and C). For shorter incubation times the stem structure was still partially intact (Fig. 4B), whereas longer incubation produced large double-stranded circles without pairing of the transposon repeats (Fig. 4C). We conclude that replication of the stem structure of the transposon was strictly dependent on concomitant unwinding by rep helicase.

\section{DISCUSSION}

Strand unwinding is a prerequisite of DNA synthesis in a replication fork. DNA helicases are possible candidates to participate in this process [27]. For DNA helicase II involvement in replication has been demonstrated [28]. Good evidence has been obtained for functions of Escherichia coli rep helicase in strand separation of duplex DNA of small bacteriophages $[2,3]$.

We have isolated the rep helicase from $E$. coli cells which contain the coding gene subcloned in a multicopy plasmid with a drug resistance marker. In order to study DNA unwinding uncoupled from replication we have chosen two DNA substrates with properties suitable for strand unwinding by $E$. coli rep helicase. The unpaired end of reannealed $\mathrm{Mu} D \mathrm{DNA}$ and the single-stranded loop structure of $\mathrm{fd}:: \operatorname{Tn} 5$ DNA provided a start for rep helicase to intrude into the double-stranded regions in order to separate the strands. The unwinding functions of rep helicase were investigated in the absence of accessory proteins required in the replication of duplex DNA of small bacteriophages like $\phi \times 174$ gene A protein or fd gene 2 protein. Electron microscopic visualization of unwinding intermediates revealed rep helicase activity which is difficult to detect in biochemical assays for strand separation. In the enzymatic assay unwound strands or self-annealing DNA like the stem of a transposon rapidly reanneal before cleavage of the single-stranded DNA. We have demonstrated here that in long double-stranded molecules the rep helicase can unwind only parts of the duplex DNA. Shorter double-stranded sequences like the 1500-base-pair repeat of transposon-5 DNA can be completely separated by rep helicase. Without unwinding, the inverted repeat of the transposon near the initiation site of fd single-stranded to RF conversion seems to interfere with proceeding DNA synthesis. The block of replication apparently increases initiation of complementary strand synthesis at various sites on the genome. This is consistent with the result that the deletion of the replication origin for complementary strand synthesis of the filamentous phage M13 still allows phage propagation although at a reduced rate [29]. Also bacteriophage $\mathrm{T} 7$ exposes secondary replication origins if the normal initiation site is deleted [30]. On the other hand, RNA polymerase holoenzyme saturated with active $\sigma$-factor strongly diminishes initiation outside the primarary origin of replication [31]. The use of secondary origins in vitro might therefore be a possible but rare event.

For replication of $\mathrm{fd}:$ : Tn5 DNA in vitro in the presence of rep helicase the unwinding reaction is not fast enough to prevent a cessation of replication at the inverted repeat structure. As a consequence multiple initiation also occurs. Furthermore, rep helicase starts unwinding the doublestranded DNA segment whenever replication reaches another initiation site. This event is seen in the electron microscope as displaced single-stranded tails in the replicated fd: : Tn 5 DNA. The large hairpin region as used for the primary origin in wild- 
type fd DNA [32] apparently prevents strand displacement after replication of the whole genome. This is concluded from the fact that replication of $\mathrm{fd}$ single strands did not produce double-stranded circles with tails.

\section{REFERENCES}

1. Denhardt, D. T. (1977) in Comprehensive Virology, (FraenkelConrat, H. \& Wagner, R. R., eds) vol. 7, pp. 1-104, Plenum Press, New York.

2. Kornberg, A., Scott, J. F. \& Bertsch, L. L. (1978) J. Biol. Chem. $253,3298-3304$.

3. Geider, K., Bäumel, I. \& Meyer, T. F. (1982) J. Biol. Chem. 257, 6488-6493.

4. Arai, N. \& Kornberg, A. (1981) J. Biol. Chem. 256, 5294- 5298.

5. Abdel-Monem, M. \& Hoffmann-Berling, H. (1980) Trends Biochem. Sci. 5, $128-130$.

6. Abdel-Monem, M., Dürwald, H. \& Hoffmann-Berling, H. (1977) Eur. J. Biochem. 79, $39-45$.

7. Schnös, M. \& Inman, R. B. (1970) J. Mol. Biol. 51, $61-73$.

8. Kuhn, B., Abdel-Monem, M., Krell, H. \& Hoffmann-Berling, H. (1979) J. Biol. Chem. 254, 11343-11450.

9. Scott, J. F., Eisenberg, S., Bertsch, L. L. \& Kornberg, A. (1977) Proc. Natl Acad. Sci. USA, 74, 193-197.

10. Yarranton, G. T. \& Gefter, M. L. (1979) Proc. Natl Acad. Sci. $U S A, 76,1658-1662$

11. Lane, H. E. D. \& Denhardt, D. T. (1975) J. Mol. Biol. 97, 99-112.

12. Taucher-Scholz, G., Abdel-Monem, M. \& Hoffmann-Berling, H. (1983) in UCLA Symposia on Molecular and Cellular Biology. (Cozzarelli, N. R., ed.) New Series, vol. X, A. R. Liss, New York, in the press.

13. Meyer, T. F. \& Geider, K. (1979) J. Biol. Chem. 254, $12636-$ 12641.
14. Beyreuther, K., Berthold-Schmidt, V. \& Geider, K. (1982) Eur. J. Biochem. 123, 415-420.

15. Eisenberg, S. J., Scott, J. F. \& Kornberg, A. (1976) Proc. Natl Acad. Sci. USA, 73, 1594-1597.

16. Burgess, R. R. \& Jendrisak, J. J. (1975) Biochemistry, 14, 46344638.

17. Diamant, B., v. Redlich, D. \& Glick, D. (1967) Anal. Biochem. 21, $135-146$.

18. Herrmann, R., Neugebauer, K., Zentgraf, H. \& Schaller, H. (1978) Mol. Gen. Genet. 159, 171-178.

19. Scott, J. F. \& Kornberg, A. (1978) J. Biol. Chem. 253, 3292-3297.

20. Bolivar, F. (1978) Gene, 4, 121-136.

21. Davis, R. W., Simon, M. \& Davidson, N. (1971) Methods Enzymol. 21, 413-428.

22. Daniell, E., Abelson, J., Kim, J. S. \& Davidson, N. (1973) Virology, 51, 237-239.

23. Geider, K., Beck, E. \& Schaller, H. (1978) Proc. Natl Acad. Sci. $U S A, 75,645-649$.

24. Geider, K. \& Kornberg, A. (1974) J. Biol. Chem. 249, 3999-4005.

25. Schildkraut, C. L., Richardson, C. C. \& Kornberg, A. (1964) J. Mol. Biol. 9, 24-45.

26. Kolodner, R. \& Richardson, C. C. (1978) J. Biol. Chem. 253, 574584.

27. Geider, K. \& Hoffmann-Berling, H. (1981) Annu. Rev. Biochem. $50,233-260$.

28. Klinkert, M.-Q., Klein, A. \& Abdel-Monem, M. (1980) J. Biol. Chem. 255, 9746-9752.

29. Kim, M. H., Hines, J. C. \& Ray, D. S. (1981) Proc. Natl Acad. Sci. USA, 78, 6784-6788.

30. Tamanoi, F., Saito, H. \& Richardson, C. C. (1980) Proc. Natl Acad. Sci. USA, 77, 2656-2660.

31. Kaguni, J. M. \& Kornberg, A. (1982) J. Biol. Chem. 257, 54375443.

32. Meyer, T. F., Geider, K., Kurz, C. \& Schaller, H. (1979) Nature, $278,365-367$.

I. Bäumel, T: F. Meyer, and K. Geider, Abteilung für Molekulare Biologie, Max-Planck-Institut für medizinische Forschung, Jahnstraße 29, D-6900 Heidelberg, Federal Republic of Germany 